\title{
Cumhuriyet Öncesi Dönem (1909-1923) Gençliği Konu Edinen Süreli Yayınlar (Dergiler)
}

\author{
DOI: $10.26466 /$ opus. 382644
}

\section{$\underline{\text { Savaș Karagöz }}$}

\author{
*Dr. Öğr.Ü. Aksaray Üniversitesi, Eğitim Fakültesi, Eğitim Bilimleri Bölümü Aksaray \\ E-Posta: savaskaragoz@aksaray.edu.tr ORCID: $\underline{\text { 0000-0002-4410-9214 }}$
}

\section{Öz}

Bu çalışmanın amacı Cumhuriyet öncesi dönem gençliğinin eğitimi üzerine dile getirilen Bu araştırmanın amacı Cumhuriyet Öncesi dönemde gençliğgi çeşitli açılardan konu edinen süreli yayınları tespit etmektir. Bu amaç çerçevesinde tarama modeli kullanılarak Milli Kütüphane, TBMM kütüphanesi gibi Osmanlıca eserlere kaynaklık eden kurum ve kuruluşlarda araştırmalar yapılmıştır. Araştırma sonucunda Cumhuriyet öncesi dönem gençliği konu edinen dergileri tantııcı bilgiler verilmiştir. Bu dergiler ise; Gençlik Âlemi (1913), Gençlik Duygusu (1911), Genç Türk (1910), Gençler Defteri (1914), Gülizar (1909), Genç Kalemler (1919), Genç Tabip (1911), Gençlik (1911), Genç Kimyager (1912), Gençler Derneği (1914), İdman (1914), Genç Kadın (1918), İzdivaç (1918), Genç Sanatkâr (1918), Genç Kalemler (1919), Genç Kadın (1919), Genç Yolcular (1919), Gençler Dünyası (1920), Gençler Derneği (1914), Genç Müslüman (tarihi yok) olarak belirlenmiştir. Günümüzde gelişmiş toplumlar arasında yer alabilmek, bilgi toplumunun niteliklerine sahip olabilmek için bilinçli, bilgili, kültürel değerleriyle donanmış gençliğe ihtiyacımızın olduğu gibi, cumhuriyet öncesi dönemde de bu nitelikte bir gençliğe ihtiyacımı olduğu düşüncesinin olduğ u görülmüştür. Özellikle gençlik üzerine ve gençlerden beklenilen duygu, düşünce, tutum ve davranışların neler olmasının yanında, aile ve ebeveynlerin de gençlere karşı nasıl hareket etmeleri konusunda okul ve öğretmenin yanı sıra, dönemin gazete ve dergiler de bilgilendirme kaynağı olarak kullanılmışıtı. Bu amacı gerçekleştirmek için sadece aile, okul ve mahalleden alınan bilgi, kültür ve değerlerin yanında süreli yayınlardan da yararlanıldı̆̆ı görülmüştür.

Anahtar Kelimeler: Gençlikve süreli yayınlar, Cumhuriyet, II. Meşrutiyet Dönemi, Eğitim Tarihi

OPUS @ C Uluslararası Toplum Araştırmaları Dergisi-International Journal of Society Researches ISSN:2528-9527 E-ISSN : 2528-9535

http://opusjournal.net 


\title{
Periodical Publications on The Time Youth Before The Republic
}

\begin{abstract}
The objective of this research to determine the periodical publications that are subject to various aspects of youth in the Pre-Republic period. Within the scope of this aim, some researches have been carried out using the institutions such as National Library, TBMM Library which are sources of Ottoman artifacts. As a result of the research, some information was given about magazines on the time youth before the Republic. These magazines are determined as Gençlik Âlemi (1913), Gençlik Duygusu (1914), Genç Türk(1910), Gençler Defteri (1914), Gülizar (1909), Genç Kalemler (1919), Genç Tabip (1911), Gençlik (1911), Genç Kimyager (1912), Gençler Derneği (1914), İdman (1914), Türk Çocuğu (1914), Genç Kadın (1918), Genç Sanatkâr (1918), Genç Kalemler (1919), Genç Kadın (1919), Genç Yolcular (1919), Gençler Dünyası (1920), Genç Müslüman Today, as well as we need young people who are conscious, knowledgeable, and culturally valued, it is thought that we needed young people in these qualities in the pre-republican period to be among the developed societies and to have the qualities of this society. In addition to what is the emotions, thoughts, attitudes and behaviors that are particularly expected of young people, as well as the school and the teacher, newspapers and magazines in the period were used as information sources for their parents to act against the youth. In order to achieve this aim, it has been seen that not only the information, culture and values taken from family, but also the school and the local area are utilized in the periodical publications.
\end{abstract}

Keywords: Youth and periodicals, The Republic, II. Constitutional Period, History of Education

OPUS (c) Uluslararası Toplum Araştırmaları Dergisi-International Journal of Society Researches ISSN:2528-9527 E-ISSN : 2528-9535

http://opusjournal.net 


\section{Giriş}

Günümüzde gelişmiş toplumlar arasında yer alabilmek, bilgi toplumunun niteliklerine sahip olabilmek için bilinçli, bilgili, kültürel değerleriyle donanmış gençliğe ihtiyacımızın olduğu gibi, cumhuriyet öncesi dönemde de bu nitelikte bir gençliğe ihtiyacımız olduğu düşüncesinin olduğu görülmektedir. Her döneminin kendine özgü özellikleri bir takım ihtiyaçları da beraberinde getirmiştir. Özellikle gençlik üzerine ve gençlerden beklenilen duygu, düşünce, tutum ve davranışların neler olmasının yanında, aile ve ebeveynlerin de gençlere karşı nasıl hareket etmeleri konusunda okul ve öğretmenin yanı sıra, dönemin gazete ve dergiler de bilgilendirme kaynağı olarak kullanılmıştır.

Yeni Türkiye Cumhuriyeti eğitiminin düşünce yapısının oluşmasında süreli yayınlar II. Meşrutiyet döneminde de eğitimle ilgili dile getirmiş oldukları konuların ve görüşlerin aktarımında önemli rol oynamışlardır. $\mathrm{Bu}$ konulardan bir tanesi ise gençlik olmuştur. Her millette olduğu Cumhuriyet öncesi dönemde de millet olarak Türk gençliğinin sağlam karakterde, milli terbiye almış ve alması gerektiği, vatanına ve milletine bağlı, sağlıklı bireyler olarak yetişmesi amaç edinilmiştir. $\mathrm{Bu}$ amacı gerçekleştirmek için sadece aile, okul ve mahalleden alınan bilgi, kültür ve değerlerin yanında süreli yayınlardan da yararlanılmıştır (Karagöz, 2014, s. 24). Bunun yanında Cumhuriyet dönemi süresince de Türkiye'de yayımlanan eğitim dergilerinde gençlik konusu sıkça ele alınmış, konuyla ilgili çok sayı da makale ve yazı yayımlanmıştır (Güçlü, 2015; Güçlü, 2016).

Bu nedenle eğitim sistemimizin değişen ve gelişen koşullara cevap vermesi gerekmektedir. Fakat eğitim sistemimizin değişen ve gelişen şartlara cevap verebilmesi için geçmişimizin iyi bir şekilde analiz edilmesi ve bu analizlerden günümüz için dersler çıkarılması gerekmektedir. Çünkü gelecekle ilgili alınan kararların anlamlı olması, geçmiş dönemin en iyi şekilde analiz edilmesi ile yakından ilgilidir (Güçlü ve Özdemir, 2017, s.145).

Bu yönüyle dergiler yeni üretilen bilgilerin halka iletilmesinde önemli bir yere sahiptir, dergiler dönemi canlı bir şekilde karakterize etmektedir. İçinde bulunduğu döneme tanıklık eden dergilerin eğitim öğretim işlevi 
de görmektedir. Bilgilerin yenilenmesinde ve aktarılmasında rol oynayan dergilerin dünya düşünce hayatında olduğu kadar Türk düşünce hayatında da önemli bir yere sahiptir (Doğan, 1997, s.64).

Süreli yayınlar, kronik olarak siyasal, sosyal ve ekonomik alandaki önemli gelişmeleri tespit eden tarihi belgelerdir. Yenilikçi fikir, görüş ve düşüncelerin açıklanmasında ve toplumun aydınlatılmasında önemli rolü olan bu dergiler ayn zamanda sosyal hayatın şekillenmesinde de önemli etki gücüne sahiptir (Şimşek, 2002, s.26).

II. Meşrutiyetin ilanından 1927 yılına kadar çeşitli alanları konu edinerek yayınlanan dergiler den 1531 tanesin yayın imtiyazı aldığı tespit edilmiştir (Gazel ve Ortak, 2006, s.228). Bunlardan 1250'sinin II. Meşrutiyet döneminde alınmış olması dikkat çekicidir.

Cumhuriyet dönemindeki Türk eğitim düşüncesini, eğitim yapısını ve mevzuatını anlayabilmek için İkinci Meşrutiyet dönemi eğitimini iyi bilmek gereklidir. İkinci Meşrutiyet döneminin, Türk eğitim tarihinde eğitim üzerine en çok yazının yazıldığı, eğitim sorunlarıyla en çok ilgilenilen ve deneyimler kazanılan bir dönem olmuştur (Ergün, 1996, s.145).

Duman ve Dilaver (2011)'e göre II. Meşrutiyet dönemi, ülke ihtiyaçlarına uygun milli bir eğitim biçiminin arayış dönemi olmuş ve bu dönemde yeni bir nesil yetiştirme düşüncesini hayata geçirerek toplum yapısını değiştirecek, tüketici memurlar yerine üretimci, girişimci şahsiyetler yetiştirecek bir eğitim sistemi kurulmak istenmiştir

Cumhuriyet dönemi eğitiminin adeta laboratuarını oluşturan II. Meşrutiyet Döneminde çeşitli alanlarda yayınlanmış çok sayıda süreli yayınlar görülmüştür. Bunlar arasında özellikle eğitim ve öğretim, kadın ve gençlik üzerine ağırlıklı olarak yayınların yapıldığı görülmüştür.

\section{Yöntem}

1908- 1923 yılları arası gençliği konu edinen dergiler Mili Kütüphane, Hakkı Tarık Us Kütüphanesi, Türkiye Büyük Millet Meclisi Kütüphanesi veri sistemleri taranarak ilgili süreli yayınlar incelenerek belirlenmeye çalışılmıştır. 1908-1923 yılları arası gençlik üzene yayınlanmış olan Gençlik Âlemi (1913), Gençlik Duygusu (1911), Genç Türk(1910), Gençler Defteri (1914), Gülizar (1909), Genç Kalemler (1919), Genç Tabip (1911), Gençlik (1911), Genç Kimyager (1912), Gençler Derneği (1914), İdman 
(1914), Türk Çocuğu (1914), Genç Kadın (1918), Genç Sanatkâr (1918), Genç Kalemler (1919), Genç Kadın (1919), Genç Yolcular (1919), Gençler Dünyası (1920), Genç Müslüman (tarihi yok) süreli yayınlar tarama modeli kullanılarak içerik analizi yapılmıştır.

Karasar (1999)'a göre, tarama modelinin temel özelliği, geçmişte ya da halen var olan bir durumu, var olduğu şekliyle betimlemeyi amaçlayan bir araştırma yaklaşımı olmasıdır. Bu modelde araştırmaya konu olan her neyse onları değiştirme ve etkileme çabası yoktur. Bilinmek istenen şey meydandadır. Amaç o şeyi doğru bir şekilde gözlemleyip belirleyebilmektir. Asıl amaç değiştirmeye kalkmadan gözlemektir. Bu araştırmada veriler, Osmanlıca belge tarama ve tercüme etme yoluyla elde edilmiştir.

\section{Bulgular}

1908-1923 yılları arası doğrudan gençliği konu edinen süreli yayınlarla ilgili yapılan alan taramasında Gençlik Âlemi (1913), Gençlik Duygusu (1914), Genç Türk(1910), Gençler Defteri (1914), Gülizar (1909), Genç Kalemler (1919), Genç Tabip (1911), Gençlik (1911), Genç Kimyager (1912), Gençler Derneği (1914), İdman (1914), Genç Kadın (1918), Genç Sanatkâr (1918), Genç Kalemler (1919), Genç Kadın (1919), Genç Yolcular (1919), Gençler Dünyası (1920), Genç Müslüman (tarihi yok) gibi dergilere ulaşılmıştır.

Bunların yanında gençlerin eğitimi ile ilgili olarak ayrıca 1908-1923 yılları arası yayın hayatına başlayan eğitim dergileri ise Yeni Mektep (Tevfik Fikret1908), Envarul-ulum (1910), Daruşşafaka (1911), Yeni Fikir Ethem Nejat (1911), Yeni Mektep Sabri Cemil (1911), Tedrisat Mecmuasi (1909), Talebe Defteri (1913), Türk Yavrusu (1913), Resimli Mektep Âlemi (1913), Türk Çocuğu İzmir (1914), Milli Talim ve Terbiye Cemiyeti Mecmuası (1916), Muallim (1916), Edebiyat Fakültesi Dergisi (1916), Muallim (1916), Halkalı Ziraat Mektebi (1917), Öksüz Yurtları (1917) Çırak Mektepleri (1918), Yeni Nesil (1921), Tedrisat-1 Íptidaiye Mecmuası (1225/) Anadolu Terbiye Mecmuası (1922), Milli Mefkûre (1922), Terbiye ve Oyun (Selim Sırrı 1922), Muallimler Birliği (1922-1927), Muallimler Mecmuası (1922-1927), Türkiye Cumhuriyeti Muallimler Birliği Umumi Kongresi 
Zabıtları, Talebe mecmuası (1923) gibi süreli yayınların olduğu görülmüştür.

Genç kız ve kadınlara yönelik ise Kadın (1909), Hanımlar Alemi (1914), Kadınlar Saltanatı (1920), Diyane (1920), Hanım (1911), Hanımlara Mahsus Gazete (1905), Kadınlar Dünyası (1914), Türk Kadını (1919) gibi çok sayıda süreli yayınların da faaliyet gösterdiği görülmüştür (2015, s.679).

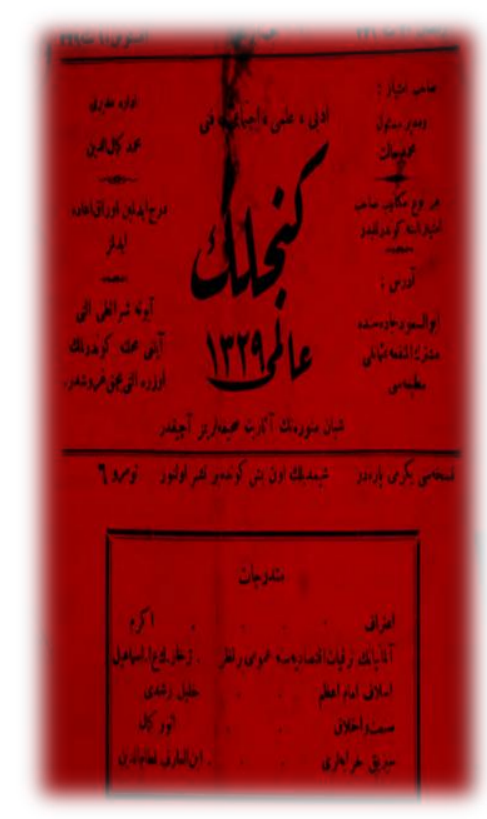

Araştırmamıza konu olan gençlik dergilerinin yayın hayatına başlama tarihi, imtiyaz sahibi, yazarları, amacı ve başlıca ele aldıkları konular aşağıda verilmiştir.Gençlik Alemi

1329 (1913) tarihinde yayın hayatına başlayan dergini İmtiyaz sahibi Mehmed Halid'tir. Her sayısı on sayfa olup toplam altı sayı yayınlanmıştır. Son sayısı olan altınc1 sayisinda yer alan yazar kadrosunda İsmail, Halil Rüştü, Enver Kemal, Arif Nizamettin yer almaktadır. Derginin başlica ele almış olduğu konulara bakıldığında;

- Gençlik

- Sanat Eğitimi

- Yabanci ülkelerdeki iktisadi gelişmeler (Almanya örneği)

- Almanya'nın eğitim, sanat, ticaret hayatındaki gelişmelerde gençliğin yeri. 1870, 1871, 1875, 1880,1887, 1904, 1906 l1 yıllardaki ticari gelişmelerden bahsedilmiştir. Hamburg deniz filosunun deniz ticaretinde Amerika, Norveç ve Fransa'dan daha üstün olduğu belirtilmiştir.

- Değerler eğitiminde İmam-1 Azam

- Gençlerde sanat ve ahlak: sanat konusunda en büyük ihtilafın sanatta ahlaki değerlerin aranıp aranmaması konusu üzerinde ayrıntılı olarak durulduğu görülmüştür. 


\section{Gençlik Duygusu}

15 Mart 1330 (1914) tarihinde yayın hayatına başlayan dergini İmtiyaz sahibi Kaymakam zade Ahmet Necati'dir. Dergi, Türk İslam gençliğinin milli, dini, vatani, içtimai ve iktisadi yönden ilerlemesine katkı sunmayı amaç olarak belirtmektedir.

Derginin içeriğine bakıldığında milli, dini, vatani, içtimai ve iktisadi

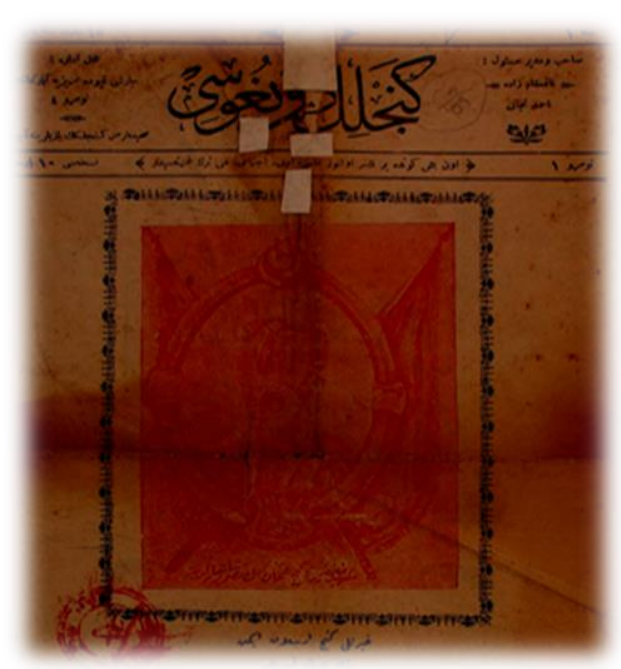
konulara ait manzumelerden ve tiyatro çalışmalarından bahsedilmiştir. Derginin incelenen ilk sayısında Şehzadebaşı Millet Tiyatrosunda gündüz hanımlara, gece ise beylere yönelik "Genç Osman" isimli tiyatro çalışması yapıldığı ve devlet erkânından çok sayıda katılımcı olduğu bilgisi paylaşılmıştır. Yazar kadrosunda Halil Rüştü, Veziriazam Hakkı yer almaktadır.

\section{Genç Türk}

1326 (1910) tarihinde yayın hayatına başlayan derginin İmtiyaz sahibi Ziya Şakir Bey ve sorumlu müdürü Sabahaddin Bey'dir. Altıncı sayısında yer alan yazar kadrosunda İsmail, Halil Rüştü, Enver Kemal yer almaktadır. Derginin başlıca ele almış olduğu konulara bakıldığında; Demokrasi mesleğine hizmet etme temel amaçları olarak belirtilmiş. Amerika'da

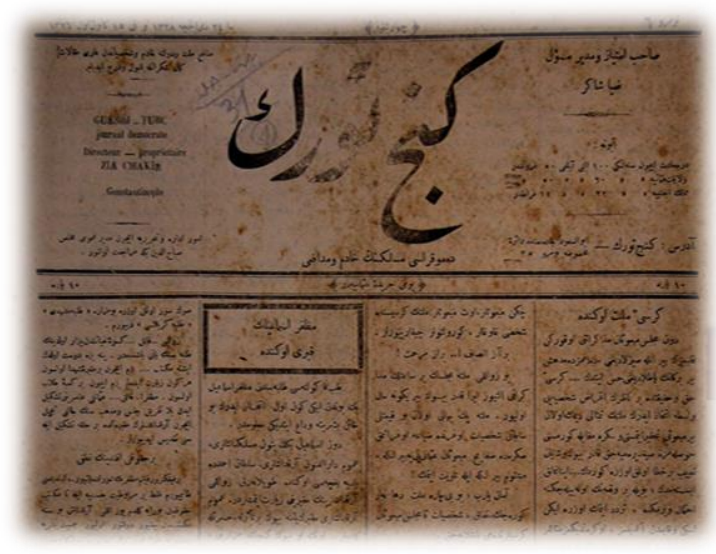


demokratların başarısı, Girit Meselesi, Bulgaristan, İran ve Rusya ile ilgili genel durum üzerinde durulduğu görülmüştür. Gençlerin eğitimi ile ilgili yabancı ülke eğitim sistemleri hakkında bilgiler verilmiş(Rusya vb. ülkeler), Gençlerin sağlık konusunda bilinçli yetişmeleri önerilmiş. O dönem için klora vebası ve korunma yolları hakkında ayrıntılı bilgiler verilmiş. Verem hastalığının tedavisi anlatılmıştır. Gençlik döneminde sağlıklı yaşam ve beden terbiyesinin önemi üzerinde durulmuştur.

\section{Gençler Defteri}

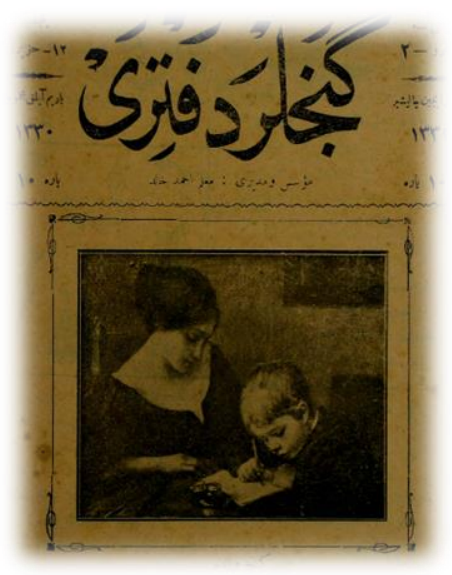

İkinci sayısı 12 Haziran 1330 (1914) ) tarihinde yayınlan yarım aylık mecmuanın imtiyaz sahibi Muallim Ahmet Halid'tir. Dergi, gençler için çalışmayı amaç olarak belirtmektedir. Derginin içeriğine gençlere yönelik ödüllü bilmeceler, sancağıma, mekteplerde bayrak bayramı, yazı yarışması (genç annelere yönelik), müzik eğitimi (Nahit'in Kemanı), en ucuz kitap nerede satılır, garp alemindeki gelişmeler, imtihanların şekli ve olumsuzlukları, ihtiyarlara hürmet, yerli malı kullanımının önemi gibi sosyal konularda gençleri bilgilendirmeye yönelik yazılar yer almaktadır. Yazar kadrosunda Muallim Hikmet, Zeki Nejdet, Suad Fahir, Mehmet Esat, Şehabettin, Mehmet Muhittin, Muallim Esat yer almaktadır. 


\section{Gülizar (1909)}

İlk sayısını 16 Mart 1325 (1909) tarihinde yayınlamıştır. 1326(1910) başlayan derginin İmtiyaz sahibi Mahmut Nedim Bey'dir. Gençlerin ilmi, edebi, ahlaki yönden terakki(ilerleme) etmelerine hizmet eden Osmanlı mecmuası olarak kendilerini tanıtmışlardır.Derginin başlıca ele almış olduğu konulara bakıldığında; Encümen-i muallim 'in faaliyetleri, Maarifin 1slahı (Mekatibi İdadi ve Rüştiye), Selahaddin Eyyübi, Ahlak ve gençlik, ahlak üzerine şiirlerin yanı sıra özellikle mevcut maarif sisteminin durumu hakkında maarifin ıslahı, usulü terbiye, mektebi idadi ve rüştiyeler ve mekteplerdeki imtihan(sınav) sistemi üzerinde durulmuştur. Yazar kadrosunda ise Şehabettin, İbnul Emin Mahmut Kemal, Muallim Bedrettin, Üsküdar İdadi Müdürü İrfan bey, Namık Ekrem, Mehmet Hüsnü ve Ahmet Nesim yer almıştır.

\section{Genç Kalemler (1919)}

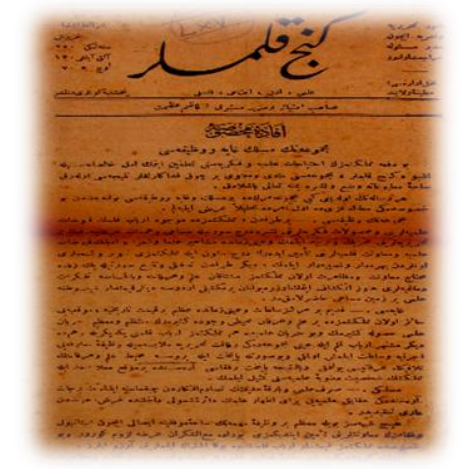

22 Temmuz-4 Eylül 1335 tarihinde yayın hayatına başlamış 1'inci ve 2'inci sayı yayınlamışlardır. Derginin İmtiyaz sahibi Kazım Azimet Bey'dir. İlmi, Edebi, içtimai ve felsefi bir mecmua olarak yayın hayatına başlamıştır. Derginin başlıca ele almış olduğu konulara bakıldığında; Hukuk, Ahlak, Edebiyat, sosyoloji, Felsefe konularında gençlere yönelik önerilerde bulunulmuştur. Yazar kadrosunda ise Mehmet Hikmet, Zeki Nejdet, Mehmet Esat yer almıştır. 


\section{Genç Kalemler (Şiir ve His) (1909)}

Yayın hayatını 1909-1912 yılları arasında sürdüren derginin imtiyaz sahibi Hüseyin Hüsnü ve sorumlu müdürü İsmail Hakkı'dır. Derginin İmtiyaz sahibi Kazım Azimet Bey'dir İsmail Hakkı Hüseyin Hüsnü, İsmail Süphi, Mustafa Haluk, Tevfik Fikret, Tahsin, Müfit Galip, Mahmut Ragıp, Ali Canip Amacı ve Dile getirdikleri başlıca Konular Vefa, Vatan, Terakki, Millet, Latin tarihi edebiyatı, Sosyoloji, maarif ve genç kadınlar (kadınların eğitimi).

\section{Genç Tabip (1911)}

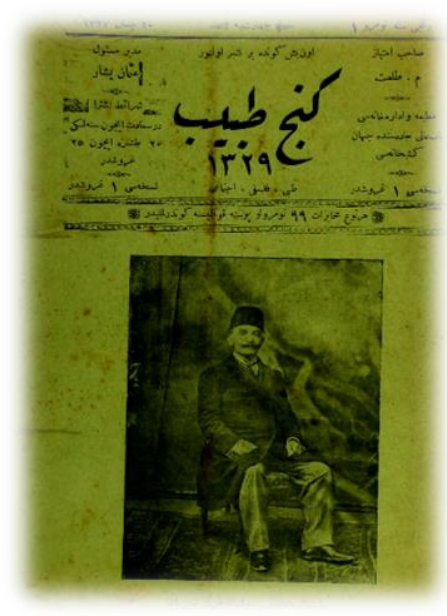

1-2 sayıları (20 Nisan-5 Mayıs 1327) tarihinde yayın hayatına başlamıştır. Derginin İmtiyaz sahibi Mahmut Talat'tır. Sorumlu müdürü Osman Yaşar'dır. Tibbi, felsefi ve içtimai mecmua olarak yayın hayatına başlamıştır.

Derginin başlıca ele almış olduğu konulara bakıldığında; Terbiye-i Bedeniye (Beden eğitimi), Sağlık, Fizyoloji, Jimnastik ve sağlık, hayat mücadelesi, öğrenci hayatı, aile sağlı̆̆ı, ciğerlerin gıdası, sanayii nisvan gibi konularda gençlere yönelik önerilerde bulunulmuştur. Yazar kadrosunda ise Esat Muhlis, Ziya Fikret, Osman Yaşar, Zeki Nejdet, Muallim Doktor Kemal Canip, Tevfik Vacit, Nihat Refik yer almıştır. 


\section{Gençlik (1911)}

1911 yılında yayın hayatına başlayan derginin imtiyaz sahibi Mahmut Rafet Bey'dir. "Gençliğin his ve fikirlerine tercüman olmak" sloganiyla yayın hayatına başlamıştır. Anadolu gençliğinin terakkisine çalışır. Başlıca ele alınan konular eski ve yeni lisan(dil), Milli Edebiyat, Garba doğru, Millete doğru, Edebiyat kitapları, Milli ediplerimiz ve Ey gençler... Yazar kadrosunda Ahmet Şevket, Hilmi Ethem, Rasim Haşmet, Mehmet Sırrı, Mehmet Şükrü yer almıştır.

\section{Genç Kimyager (1912)}

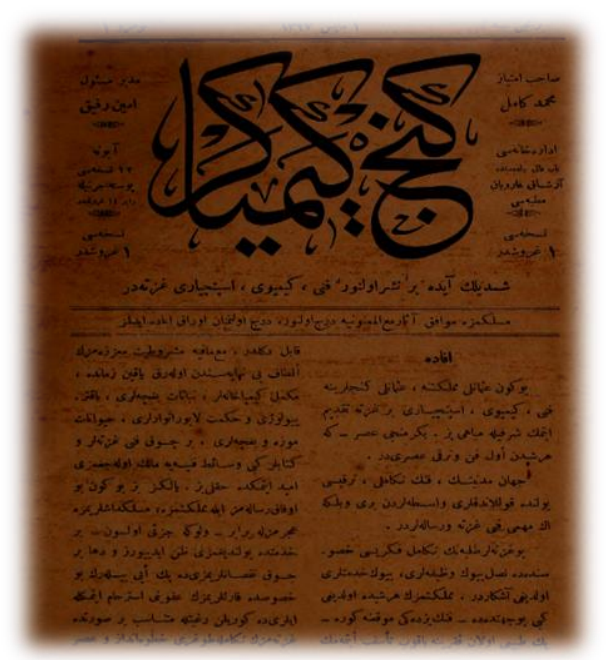

afettin Bey'dir.

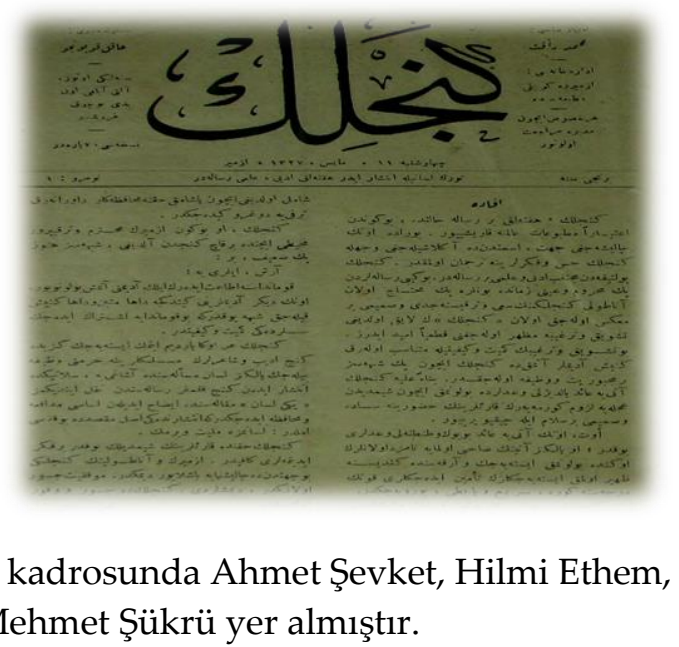

Eczac1 Mustafa Kemal Bey tarafından Mayıs 1911'de yayın hayatına başlamıştır. "20 asır her şeyden önce fen ve terakki asrıdır" düşüncesini amaç edinmiştir. Amacı ve dile getirdikleri başlıca konular ise eczacilığın önemi, bakteriyoloji, eczacilık mektebi ve gençlik, hıfzıssıhha, erkek ve kadın arasındaki fark, bel soğukluğu ve gençlere öneriler, eczacılık dersleri ve ders işleniş yöntemleri, Sağlık ve Gençlik'tir. Başlıca yazarları ise Mehmet Refik, M. Kemal ve Şer- 


\section{Gençler Derneği (1914)}

Mart 1330 (1914) yllında yayın hayatına başlamıştır. Başyazıcı olarak Mustafa Nusret yer almıştır. Amaç olarak fenni, edebi, içtimai, olarak belirlenmiştir. Ahlaklı gençlerin faydasına çalışır sloganı ile ilk sayısını yayınlamıştır. Başlıca ele almış oldukları konular ise Ahlakı tasfiye, kardeşlik, intikam, hak, bir gencin hayat, terbiye-i bedeniye, Bir Türk gencinin başarısı... Başlica yazar kadrosunda ise Mustafa Nusret, Kazım Nami, Abdi Hilmi, Abdülkerim Nadir, Kayserili Şaban Sırrı, Kahraman Hadi'dir.

\section{İdman (1913)}

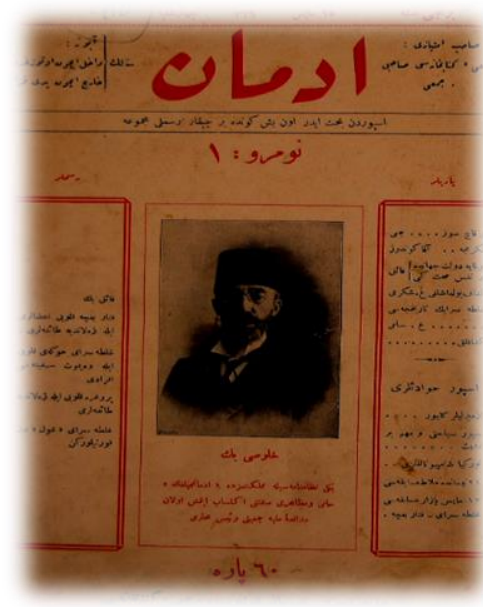

15 Mayıs 1329 (1913) tarihinde yayın hayatına başlayan derginin imtiyaz sahipliğinin Cem'i isminde bir kitapçıdır. Derginin sorumlu müdürü ise Mehmet Sadî’dir. Başlıca ele aldığı konular spor ve sağlık başlı̆ğ altında toplanabilir. Galatasaray, Fenerbahçe, Türk Gücü gibi futbol kulüplerinin tarihçesi, müsabakaları hakkında bilgiler sunmuşlardır. 2'inci sayısını Galatasaray Futbol takımının tarihçesine, yapmış olduğu müsabakalara yer vermiştir. Galatasaray futbol Kulübü fahri reisi ve Mektebi Sultani müdürü Salih arif Bey'in fotoğrafına ve İsveç Jimnastiği, jimnastik sporu hakkında bilgi verilmiştir. 3'üncü sayısını Fenerbahçe spor kulübüne ayırmıştır. Çeşitli spor dalları ile ilgili açıklayıc bilgiler verilmiştir. Yazar kadrosunda ise Abidin Daver, Ali 
Sami Yen, Aka Gündüz, Faik Bey, Burhan Felek, Selim Sırrı Tarcan yer almıştır.

\section{Genç Kadın (1918)}

1919 yılında yayın hayatına başlayan derginin imtiyaz sahibi Karahisarlı Fuat Şükrü ile Fatma Fuat'tır. Derginin amacı genç kızların ahlaki, içtimai ve edebi yönden ilerlemelerine katkı sağlamak olarak belirlenmiştir. Derginin işlemiş olduğu başlica konular ise, Kadın ve kadınlık, genç kızlar, zavallı gençler, mekteplerde ahlak, Terbiye-i fikrîye, ahlakiye ve bedeniye, kadınlık hakları, evlilik, genç kızlar ve izdivaçtır. Derginin yazar karosu ise Fatma Fuat, Nusret Kazım, F. Şükrü, fahriye Mahi'de, Hadice Nevin ve Zühdizade İhsan Bey oluşturmuştur.

\section{Genç Kadın (1919)}

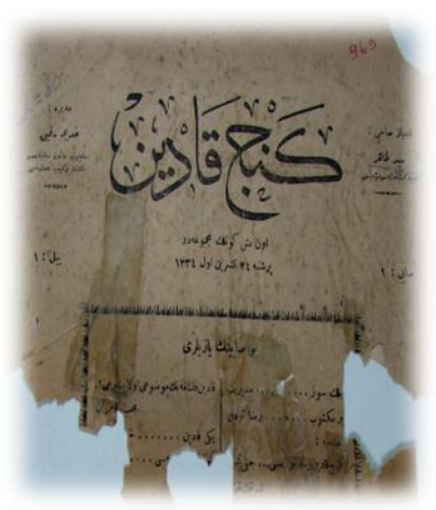

Süleyman Tahir'in imtiyazında 1918 tarihinde yayın hayatına başlayan derginin başlıca amacı genç kızların sosyal hayattaki gelişmelerine katkı sağlamak olarak ifade edilmiştir. Ağırlıklı olarak genç kadınlarla ilgili bilgiler sunulmuştur. Bu konulara bakıldığında; genç kadın ve mefkuresi, kadın felsefenin konusu olabilir mi?, Yeni kadın... Başlıca yazar kadrosu ise Riza Tevfik, Hakkı Tahsin, Mehmet Emin, İhsan makbul, Ali baha, Aliye Esad, Kemal Fevzi'dir. Bu dergide dikkat çeken nokta genç kadınlarla ilgili konuları ele alan yazarların hepsinin erkek olmasıdır. 


\section{Genç Sanatkâr (1918)}

15 Teşrînievvel 1334/1918-5 Kânunusâni 1335/1919 tarihleri arasında yayın hayatına başlamıştır. Sahipliğini ve sorumlu müdürlüğünü İbrahim Pertev yapmıştır. Aylık içtimai, edebi, fenni ve sınai gazete olarak tanıtımlarını yapmışlardır. Dergide dile getirilen konuları bakıldığında genç sanatkâr, sanatta sefirilik, ustalık ve çıraklık, Genç sanatkârlara yönelik hikâyeler, memleketimizde ehil sanatkâr yetiştiren ocaklar, yeni asır yeni zihniyet, hayatta muvaffakiyet yolları, genç sanatkârlara nasihat, tedrisatı sanaiyemiz etrafında, fenni ve sinai mesai, tahsilden dönen gençler, sanatkârlar dünyası oluşturmuştur. Derginin yazar kadrosunda İbrahim Hamdi, Hafız Cemal, Şerafettin, Ahmet Fuat, İbrahim Pertev, Şefik Nahit, Numan Sabit, Aka Orhan ve Bekir Doğan yer almıştır.

\section{Genç Yolcular (1919)}

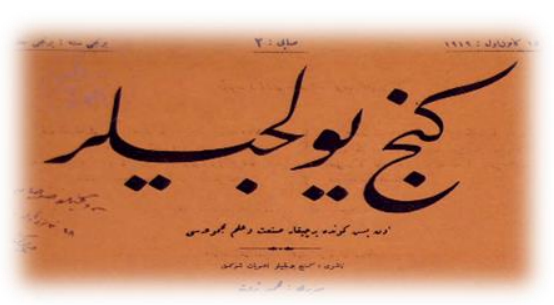

1919 yılında yayın hayatına başlayan derginin imtiyaz sahipliğini $\mathrm{M}$. Servet yapmıştır. Dergide ele alınmış olan konulara bakıldığında; Ruhiyat(psikoloji), Şiir, Edebiyat, Halk Edebiyatı, Garp Edebiyatı, Felsefe, Terbiye, Kemalettin Kamu, Kızların terbiyesi(eğitimi), Ahlak, Mehmet Akif, Yunus Emre, Sosyoloji, Gençlik, Milli Sanatlar, Milli Musiki konularının işlendiği görülmüştür. Başlıca yazar kadrosunda Mustafa Şekip, M. Servet, İhsan Raif, Necmettin Sadak, Hatemi Senih, Mehmet Vehbi, Sadri Ethem, Süleyman Hilmi, Mükremin Halil, Halil Vedat, İrfan Emin yer almıştır. 


\section{Gençler Dünyası (1920)}

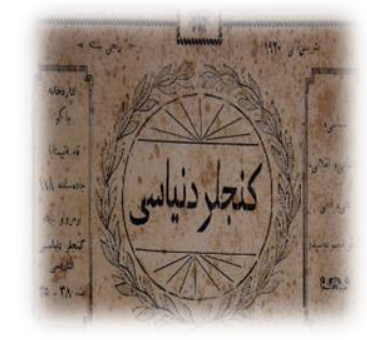

Siyasi, İçtimai, İnkılabı, Fenni, Edebi Gençlik Dergisi olarak yayın hayatına başlamıştır. Darulmuallimli gençler, gençlerin ruhu, gençler hareketi, şark gençleri kongresi gibi konularda gençleri bilgilendiren dönemin siyasi içerikli dergisidir. Başlıca yazarları ise Ethem Nejat, Mustafa Suphi, Abid Âlim'dir.

\section{Genç Müslüman (tarihi yok)}

Hakkı Baha tarafından yayınlanmıştır. Tarihi belli olmayan dergi kendisini ilmi, dini, felsefi mecmua olarak tanitıştır. Başlica ele aldığı konular dini içerikli yazıların yanı sıra realizm, determinizm, din-İslam ve terakkiyatı medeniyet Tevfik Fikret, evkafı İslamiye meseleleri olmuştur. Sonuç ve Tartışma

1909-1923 yılları arası gençliği konu eden süreli yayınların çoğunluğunun yayın hayatının kısa sürdüğü görülmüştür. Bu dergiler kısa süreli yayın hayatında bulunsalar da ele almış oldukları konulara bakıldığında içinde yaşanılan dönemin gençler üzerinde meydana getirmiş olduğu değişimin etkisi görülmüştür.

İncelenen dergilerde, gençlerin sosyal hayatta başarılı olmaları için dönemin getirmiş olduğu değişimlerden nasıl yararlanmaları gerektiği dergilerin benimsemiş olduğu görüş ve ideolojiler doğrultusunda verilmeye çalışılmıştır.

İncelenen dergilerin isimleri, ele aldıkları konular ve yazar kadrosuna bakıldığında o dönem açısından büyük bir boşluğu doldurduğu düşünülebilir. 
Sonuç olarak dergilerin ağırlıklı olarak ilmi, ahlaki, edebi, sosyal, felsefi konularda gençleri bilgilendirdikleri görülmüştür. Ele alınan konular ayrıntılı olarak sınıflandırıldığında ise;

- Yabancı ülkelerdeki ilmi ve bilimsel gelişmeler

- Milli terbiye (eğitim)

- Sanat eğitimi ve önemi

- Vatan ve millet sevgisi

- Sağliklı yaşam

- Bulaşıcı hastalıklardan kadın erkek genç olarak korunma yollar1

- Sporun önemi

- Fenerbahçe ve Galatasaray futbol kulüplerinin tarihçesi ve farklı branşlarda spor dalları

- Lisan (dil) Öğretimi

Cumhuriyet öncesi dönem içinde çeyrek asırlık bir süreçte gençlere yönelik 20'ye yakın derginin farklı konularda gençleri bilgilendirmeleri yaygın eğitim kurumu olarak değerlendirilebilir.

\section{KAYNAKLAR}

Doğan, İ. (1997). Değişen Türkiye 'de bilim ve kültür. Ankara: İmaj Yayınevi. Duman, T. ve Dilaver, H.H. (2011). Prof.dr. yahya akyüz'e armağan, türk eğitim tarihi araştırmaları, eğitim ve kültür yazıları, Ankara: Pegem A Yayıncilik.

Ergün, M. (1996). II. meşrutiyet dönemi eğitim hareketleri. Ankara: Ocak Yayınevi.

Gazel, A. A., \& Ortak, Ş. (2006) İkinci meşrutiyet'ten 1927 yılına kadar yayın imtiyazı alan gazete ve mecmualar (1908-1927), Atatürk Üniversitesi Sosyal Bilgiler Enstitüsü, 7(1), 223.

Güçlü, M. (2015). Türkiye'de 1950 ve 1980 yılları arasında süreli yayınlara yansıyan mesleki ve teknik öğretimle ilgili konuların değerlendirilmesi: Mesleki ve teknik öğretim dergisi örneği", Turkish Studies, 10(14), 363-386. 
Güçlü, M. (2016). Yeni okul dergisi'nin ele adiği eğitim sorunları açısından değerlendirilmesi (1950-1954). Nevşehir Hacı Bektaş Veli Üniversitesi, Sosyal Bilimler Enstitüsü Dergisi, 6(2), 68-85.

Güçlü ve Özdemir (2017). Eğitim hareketleri dergisi'nin türk eğitim tarihindeki yeri ve önemi. Ahi Evran Üniversitesi Sosyal Bilimler Enstitüsü Dergisi (AEÜSBED), 3(2), 145-153.

Karagöz, S., ve Duman,T., (2014). 1908-1928 Yıları arası süreli yayınlarda yer alan eğitim görüşleri ve öneriler. Uluslararası Sosyal Araştırmalar Dergisi, 7 (35), 576-594. Issn: 1307-9581.

Karagöz, S. ve Şanal, M.(2015). İkinci meşrutiyet dönemi kadın gözüyle kadın eğitimi. Uluslararası Sosyal Araştırmalar Dergisi. 8(39), 679691.

Karasar, N. (1999). Bilimsel araştırma yöntemi (9. Baskı). Ankara: Nobel Yayıncilik.

Şimşek, H. (2001). Tanzimat ve mutlakıyet dönemi çocuk dergilerinin eğitim açısından incelenmesi. Yayımlanmamış Doktora Tezi Ankara Üniversitesi Sosyal Bilimler Enstitüsü, Ankara.

\section{Kaynakça Bilgisi / Citation Information}

Karagöz, S. (2018). umhuriyet Öncesi Dönem (1909-1923) Gençliği Konu Edinen Süreli Yayınlar (Dergiler) OPUS - Uluslararası Toplum Araştırmaları Dergisi, 8(Gençlik Araştırmaları Özel Sayısı), 468-484. 